\title{
Biochemical and Photosynthetic Evaluation of Responses in Zea mays L. Under Drought Stress
}

\author{
S.S. ABU-MURIEFAH ${ }^{1}$, MOHAMED M. IBRAHIM ${ }^{2,3 *}$ and GEHAN A. ELGAALY ${ }^{4}$ \\ 'Department of Biology, Science College, Prince Noura University, Riyadh- KSA. \\ ${ }^{2}$ Department of Botany and Microbiology, College of Science, \\ King Saud University P.O. Box 2455, Riyadh 11451, Saudi Arabia. \\ ${ }^{3}$ Department of Botany and Microbiology, Faculty of Science, \\ Alexandria University, Alexandria - P.O. Box 21511, Egypt \\ ${ }^{4}$ Department of Botany and Microbiology, Female Section, College of Science, \\ King Saud University P.O. Box 22452, Riyadh, 11495, Saudi Arabia.
}

http://dx.doi.org/10.12944/CWE.9.1.13

(Received: January 10, 2014; Accepted: March 07, 2014)

\begin{abstract}
Antioxidant defense system(s), pigments content and photosynthetic activity as well as some biochemical changes under drought stress were analyzed in maize (Zea mays L. cv. Giza 21) leaves to determine the response of plant to drought stress and to elucidate the role of various protective mechanisms against oxidative stress. It was found that the application of drought stress led to changes in the carbohydrates and protein contents. Total soluble sugars, accumulated in the leaves of water-stressed plants, whereas, starch and protein contents were dropped to a small amounts compared to the control. Furthermore, plants have well-developed defense systems against reactive oxygen species (ROS), involving both limiting the formation of ROS as well as instituting its removal. Within a cell, the activities of a range of antioxidant enzymes such as superoxide dismutase (SOD), catalase (CAT), ascorbate peroxidase (APX) involved in scavenging ROS were investigated. During dehydration the SOD, APX and CAT increased significantly up to 4 days, then declined in their activities but still maintained higher than the control levels this indicates that the defense systems involved are efficient in the protection of plant cells against oxidation. In addition, there was consistent increase in the lipid peroxidation and accumulation of malondialdehyde (MDA). The levels of hydrogen peroxide were also elevated during stressing periods. In this study we are reporting the negative response of maize plants toward drought stress especially on the antioxidant enzymatic activity for the prolonged drought effect.
\end{abstract}

Key words: Drought, Oxidative stress, Reactive oxygen species (ROS), Antioxidants.

\section{INTRODUCTION}

Drought stress is considered as one of the most important environmental factors that causes osmotic stress, limiting plant growth and development. Different pathways can also be affected differently. At the whole plant level, the effect of drought stress is usually perceived as a decrease in photosynthesis and growth (Asada, 1997), and is associated with alterations in $\mathrm{C}$ and $\mathrm{N}$ metabolism. Furthermore, the imposition of biotic and abiotic stress conditions can give rise to excess concentrations of reactive oxygen species, resulting in oxidative damage at the cellular level. Therefore, a consequence of drought stress is the limitation of photosynthesis and usually accompanied by the formation of reactive oxygen species (ROS) in the chloroplasts (Smirnoff, 1993) such as the superoxide radical, $\mathrm{H}_{2} \mathrm{O}_{2}$, and the hydroxyl radical (Foyer et al., 1994). Hydrogen peroxide is especially toxic in the chloroplasts because even at low concentrations it inhibits the Calvin- cycle enzymes, hence reducing the photosynthetic carbon dioxide assimilation (Takeda et al., 1995). 
Plants are equipped with complex and a highly efficient antioxidative defense system composed of protective non-enzymatic and enzymatic protection mechanisms function to interrupt the cascades of uncontrolled oxidation in some organelles (Noctor and Foyer, 1998) and serve to maintain the antioxidants in their reduced functional state (Schwanz et al., 1996) that efficiently scavenge AOS and prevent damaging effects of free radicals (Shalata and Tal 1998).

Enzymatic protection is partly performed by superoxide dismutase (SOD, EC 1.15.1.1) that eliminates superoxide radicals $\mathrm{O}_{2}$-" and by catalase (CAT, EC 1.11.1.6) and ascorbic peroxidases (APX, EC 1.11.1.11) that degrade $\mathrm{H}_{2} \mathrm{O}_{2}$ influencing the level of lipid peroxidation (Dat et al., 2000 and Mittler, 2002) which is commonly taken as an indicator of oxidative stress, because it is induced by reactive oxygen species (ROS). Our study aimed to investigate the effect of drought stress by withholding water on some biochemical and physiological parameters in maize plant (Zea mays L.Giza 21), moreover clarifying the antioxidant enzymes activity of maize plants under drought stress.

\section{MATERIALS AND METHODS}

\section{Plant material and growth conditions}

Seeds of maize (Zea mays L. cv. Giza 21) were surface sterilized by immersion for two min in $0.1 \% \mathrm{HgCl}_{2}$ thereafter they were washed with five changes of sterile distilled water. Seeds were soaked in continuously aerated distilled water for $24 \mathrm{~h}$ in darkness. Seeds were sown in plastic pots (15 cm diameter $\times 20 \mathrm{~cm}$ height), filled with washed pure quartz sand. All pots were placed in a growth chamber under $70-80 \%$ relative humidity with 16 / $8 \mathrm{~h}$ day/night cycle and controlled temperature of $28 / 26^{\circ} \mathrm{C}$. Light intensity was $420 \mu \mathrm{mol} \mathrm{m} \mathrm{m}^{-2} \mathrm{~s}^{-1}$. Each pot was irrigated with $250 \mathrm{ml}$ of distilled water at first, then occasionally with a certain amount of water in order to keep the soil water content constant. After seven days, all plants were watered on alternate days with half strength of Hoagland solution. After 15 days from sowing one-half of the plants were subjected to drought stress by withholding water for 8 days and sampled in regular intervals for analyses. Just after harvest, the whole plants or dissected organs were blotted dry and weighed carefully for fresh weight determination, then dried in a hot-air oven at $70^{\circ} \mathrm{C}$ until a constant weight to obtain dry weight. For biochemical analyses, the second leaves were harvested and used either immediately for extractions or were stored at $-20^{\circ} \mathrm{C}$ until analysis. Each experiment was repeated twice, with a total of 20 plants in each case.

\section{Determination of carbohydrates constituents and protein content}

This was done by alcoholic extraction method. Reducing sugars were analyzed according to Irigoyen et al.,(1992), Three $\mathrm{ml}$ of the modified Nelson's reagent were added to $5 \mathrm{ml}$ of the sugar extract. The whole was mixed thoroughly in a boiling tube immersed in a vigorously boiling water bath for $15 \mathrm{~min}$. The tubes were then cooled rapidly. Three $\mathrm{ml}$ of arsenomolybdate reagent were run into each tube with gentle shaking till effervescence stopped. The colored solution was diluted to known volume and then measured at $700 \mathrm{~nm}$ using spectrophotometer (JENWAY, 6305, UK). Protein fractions were determined according to the method described by Breadford (1976) in which $5 \mathrm{ml}$ of the protein reagent ${ }^{*}$ were added to $0.1 \mathrm{ml}$ of the extract and the contents mixed by vortexing. The absorbance was measured at $595 \mathrm{~nm}$ during one hour. The concentration of protein was calculated from a previously constructed standard curve using bovine serum albumin (Fluka, analytical grade).

\section{Pigments analyses}

The photosynthetic pigments chlorophyll a, b (Chl. a, Chl. b) and carotenoids (Carot.) were determined following $\mathrm{N}, \mathrm{N}$-dimethyl formamide (DMF) method described by Inskeep and Bloom (1985). A known weight of the dissected plant leaves $(50 \mathrm{mg}$ ) were incubated in $10 \mathrm{ml}$ of DMF reagent and kept in dark at $4^{\circ} \mathrm{C}$ for 24 hours. The extract-containing pigments was decanted and the absorbance was measured at three wavelengths 647, 665 and $470 \mathrm{~nm}$ using spectrophotometer (JENWAY, 6305, UK) Formula and extinction coefficients used for determination of photosynthetic pigments were:

Chl. $\mathrm{a}=12.70 A_{665}-2.79 A_{647}$ Chl. $b=20.70 A_{647}-4.62 A_{665}$ Carotenoids $=4.2 A_{453}-(0.0264$ Chl. $a+0.426$ Chl. b $)$ 
*One hundred $\mathrm{mg}$ of Coomassie Brilliant Blue G250 was dissolved in $95 \%$ ethanol. Then $100 \mathrm{ml}$ $85 \%(\mathrm{w} / \mathrm{v})$ phosphoric acid was added. The resulting solution was diluted to a final volume of one liter and filtered

\section{Determination of lipid peroxidation}

Malondialdehyde, (MDA) content was assayed as indicators of the extent of lipid peroxidation in leaf tissue by the method of Hodgson and Raison (1991). MDA concentration was calculated using a molar extinction coefficient of $155 \mathrm{mM}^{-1} \mathrm{~cm}^{-1}$.

\section{Determination of hydrogen peroxide}

The level of $\mathrm{H}_{2} \mathrm{O}_{2}$ was measured colorimetrically as described by Jana and Choudhuri (1982). $\mathrm{H}_{2} \mathrm{O}_{2}$ level was calculated using the extinction coefficient $0.28 \mu \mathrm{mol}{ }^{-1} \mathrm{~cm}^{-1}$.

\section{Extraction of antioxidant enzyme and activity determination}

Fresh maize leaves $(\approx 0.5 \mathrm{~g}$ fresh material) were ground to a fine powder in liquid nitrogen. Frozen powder were transfer into $10 \mathrm{ml}$ of ice-cold extraction buffer containing $100 \mathrm{mM} \mathrm{K \textrm {K } _ { 2 }} \mathrm{PO}_{4} /$ $\mathrm{K}_{2} \mathrm{HPO}_{4}, \mathrm{pH} 7.8,5 \mathrm{mM}$ ascorbate, $400 \mathrm{mg}$ of insoluble polyvinylpolypyrro- lidone (PVP), and 2 \% Triton X-100 (Schwanz et al.,1996), mixed for 1 $\mathrm{min}$, and incubated on ice for $30 \mathrm{~min}$. According to Asada (1997), the elution buffer for APX contained additionally $1 \mathrm{mM}$ ascorbic acid in order to keep APX enzyme in the active state. The purified extracts were used immediately for the determination of super oxidedismutase, SOD; catalase, CAT and ascorbic peroxidase, APX activities.

\section{Enzymes assay}

Enzymatic assays were performed at $25^{\circ} \mathrm{C}$. All solutions used for analytical and enzymatic investigations were prepared with double-ionized water.

SOD (EC 1.15.1.1) activity was measured according to the method of Stewart and Bewely (1980). One unit of SOD activity was the amount of enzyme activity that caused $50 \%$ inhibition of the initial rate of the reaction in the absence of enzyme.
APX (EC 1.11.1.11) activity was assayed according to Asada (1997). One unit of APX was the amount of enzyme that oxidized $1 \mathrm{mmol}$ of ascorbate per min at room temperature.

CAT (EC 1.11.1.6) activity was assayed by monitoring the decomposition of $\mathrm{H}_{2} \mathrm{O}_{2}$ spectrophotometrically at $240 \mathrm{~nm}$ (Luck 1965). One unit of enzyme activity is equal to $1 \mathrm{mmol}$ of $\mathrm{H}_{2} \mathrm{O}_{2}$ decomposed per min.

\section{RESULTS}

\section{Effect of drought stress on the carbohydrate and protein content}

A study of the changes in the carbohydrate fractions in leaves of maize plant subjected to drought stress shows that these fractions have different patterns. For example, the total carbohydrate content under drought stress was dropped from initial values of 218.2 at the beginning of treatment to $166 \mathrm{mg} \mathrm{g}^{-1} \mathrm{DW}$ at the end of experiment (Fig 1). The corresponding values for the well-watered plants were 218.2 and $210 \mathrm{mg} \mathrm{g}$ ${ }^{1} \mathrm{DW}$ respectively. Whereas, the total soluble sugars content was consistently higher in the leaves of water-stressed plant amounted to $140.5 \mathrm{mg} \mathrm{g}^{-1} \mathrm{DW}$ at the end of experiment compared to $89.6 \mathrm{mg}$ in control (Fig 1). Non-reducing sugars were generally remained substantially higher than reducing sugars but significantly far more non-reducing sugars were accumulated relative to the control at the end of experiment (Fig1)

Table 1: Changes in chlorophyll $a$ and $b$, total chlorophyll content, total carotenoids and chlorophyll $\mathrm{a} / \mathrm{b}$ ratio in leaves of maize plant grown under drought stress for 8 days. Values were expressed as the percent of increase or reduction relative to the control

\begin{tabular}{lccccc}
\hline \multirow{2}{*}{$\begin{array}{l}\text { Time } \\
\text { (days) }\end{array}$} & Chl.a & Chl.b & Total chl. & Car. & Chl alb \\
\cline { 2 - 6 } & \multicolumn{5}{c}{$\%$} \\
\hline 0 & 100 & 100 & 100 & 100 & 100 \\
2 & 81 & 86 & 97 & 96 & 92 \\
4 & 70 & 85 & 90 & 94 & 84.5 \\
8 & 55 & 72 & 79.3 & 84.8 & 72 \\
\hline
\end{tabular}


The leaves of water-stressed plant contained significantly lower amount of starch 26.9 $\mathrm{mg} \mathrm{g}^{-1} \mathrm{DW}$, at the end of experiment, compared to121.1 $\mathrm{mg} \mathrm{g}^{-1} \mathrm{DW}$ in those of well-water plants (Fig1).

Furthermore, the results shown in Fig.2 indicate clearly that drought stress had a pronounced effect on the total soluble proteins content in leaves of maize plants. Thus, when leaves were subjected to water stress, protein content declined rapidly as compared to the control (Fig.2). At the end of exposure time, the total soluble protein in leaves of water stressed plant was $76.8 \mathrm{mg} \mathrm{g}^{-1}$ dwt compared to $206.5 \mathrm{mg}$ in control.

\section{Chlorophylls and Carotenoid Contents}

In maize leaves drought stress caused a general decrease in the pigment contents, including chlorophyll $a, b$, and $\beta$-carotene. This pattern of change was not evident in control, in which all pigments did not change statistically (data
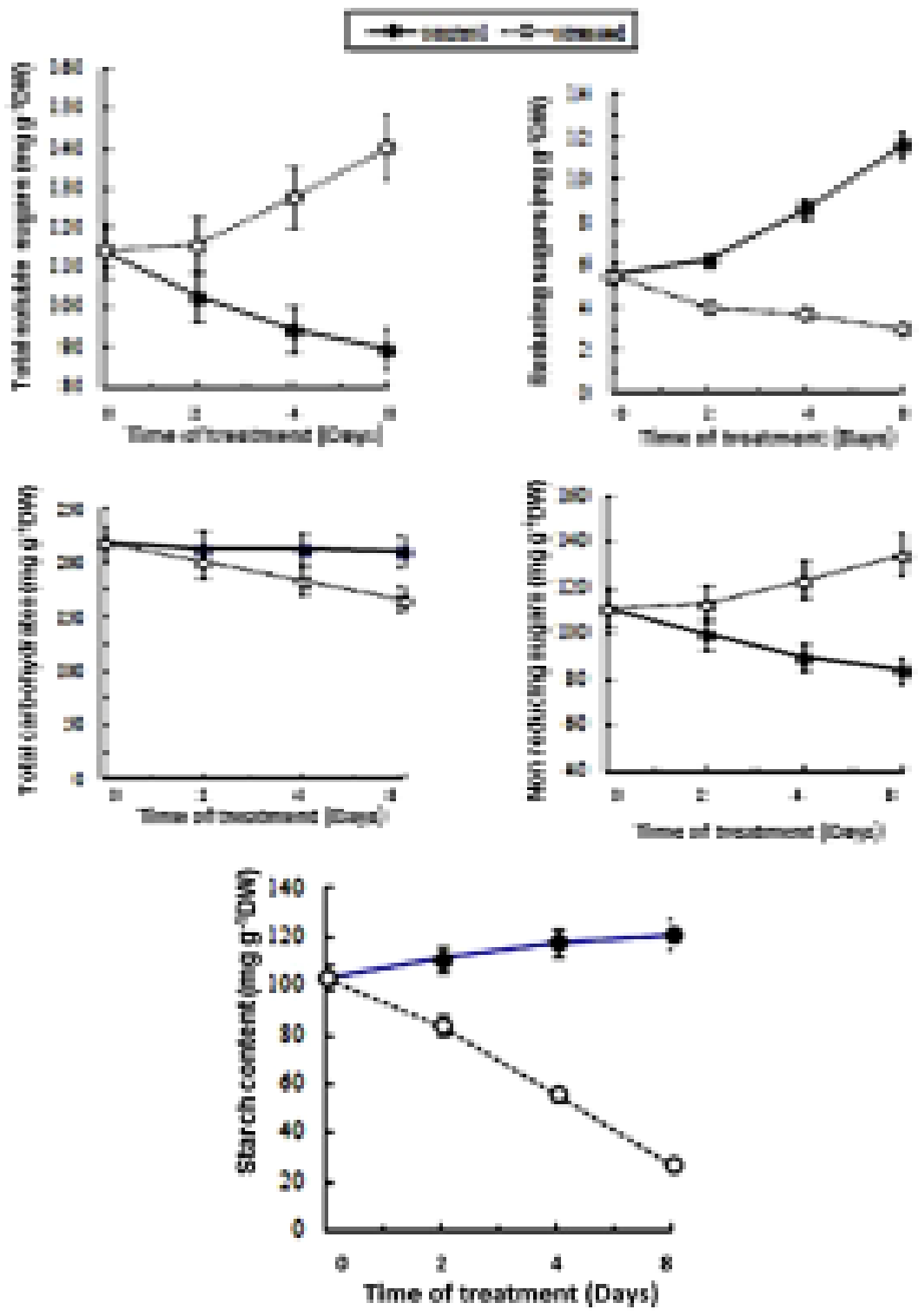

Fig. 1: Effect of drought stress on carbohydrates constituent in leaves of Zea maize plant.Value are means $\pm S E(n=5)$ 


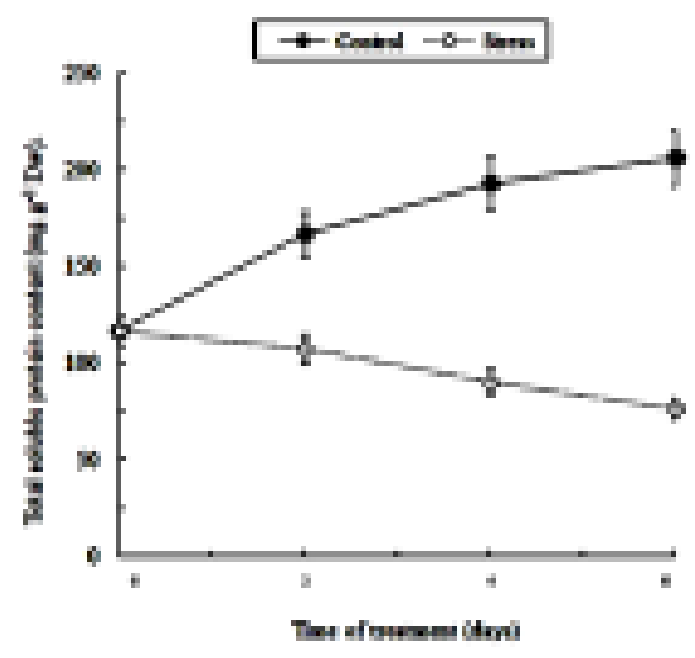

Fig. 2: Effect of drought stress on protein in leaves of Zea maize plant. Values are means \pm SE. $(n=5)$

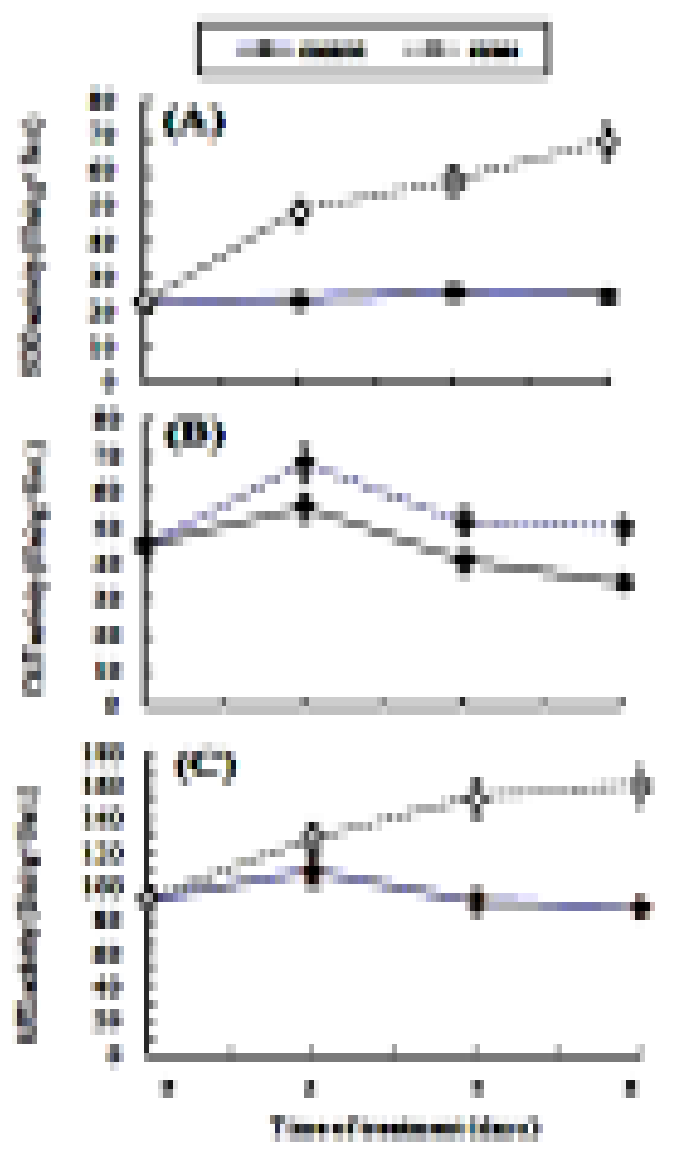

Fig. 4: Effect of drought stress on antioxidant enzymes activities in leaves of Zea maize plant. Values are means $\pm S E$. $(n=5)$
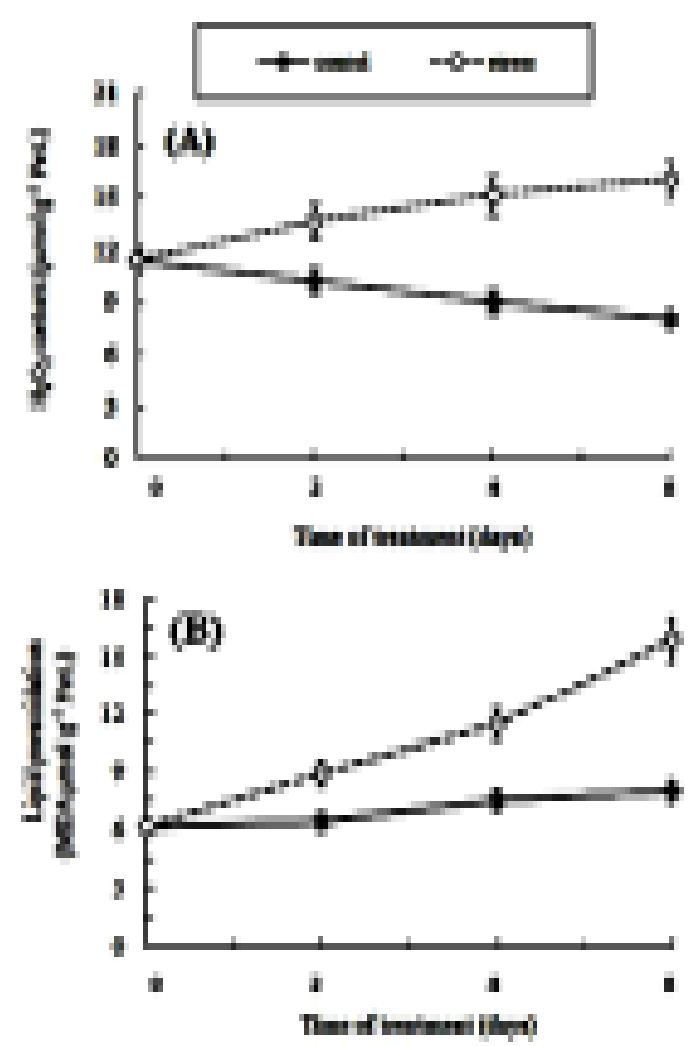

Fig. 3: Effect of drought stress on hydrogen peroxide $\left(\mathrm{H}_{2} \mathrm{O}_{2}\right)$ and lipid peroxidation (MDA) contents in leaves of Zea maize plant. Values are means \pm SE. $(n=5)$

not shown). The content of chlorophyll $a, b$ and carotenes in maize leaves under drought stress particularly at the end of experiment, were decreased by about 45 and 28 and $15.2 \%$ of control respectively. As a consequence, the $\mathrm{Chl} a / b$ ratio was decreased significantly under drought stress (Table 1).

\section{Hydrogen peroxide content $\left(\mathrm{H}_{2} \mathrm{O}_{2}\right)$}

Hydrogen peroxide has a negative effect on various biochemical processes inside the plant cell. According to our results, the level of $\mathrm{H}_{2} \mathrm{O}_{2}$ did not change significantly in control plants, during the experimental period (Fig.3A). In contrast, drought stress caused a significant increase in the generation $\mathrm{H}_{2} \mathrm{O}_{2}$ during the drought stress period. After 8 days of treatment, the production of $\mathrm{H}_{2} \mathrm{O}_{2}$ reached the maximum values, amounted to $46 \%$, compared with control. Despite the accumulation of $\mathrm{H}_{2} \mathrm{O}_{2}$ during the exposure time of water stress, did not result immediately in cell death. 


\section{Lipid peroxidation of plasma membrane}

One of the described damages provoked by water-stress is the membrane injury. This is a consequence of an oxidative burst leading to lipid peroxidation. Peroxidation can be measured by quantifying the amount of malondialdehyde, (MDA). As shown in Figure 3B, the MDA production was increased significantly with leaf ageing and was enhanced by water stress. For convenience, at the end of exposure period, control leaves produced only 7.99 imol $\mathrm{MDA} \mathrm{g}^{-1} \mathrm{FW}$., whereas drought stress greatly increased MDA, reaching 15.9 ìmol MDA g ${ }^{1} \mathrm{FW}$.

\section{Effects of drought stress on antioxidant enzymes}

The effects of drought stress on the activities of several important antioxidant enzymes such as SOD, CAT, and APX, in maize leaves, were investigated and the results are shown in Fig 4. The results clearly demonstrate that drought stress led to a significant enhancement in the activities of SOD, CAT and APX (Fig.4A, B and C) within 4 days of treatment reached almost the maximum values amounted to $123 \%, 21 \%$, and $67 \%$, respectively, relative to the control whereas the initial activities were maintained at control levels.

However, after 4 days of drought stress treatment, the activities of these antioxidant enzymes had a tendency to decrease. No significant changes in the activities of these enzymes in control were observed during experimental period. The positive response of SOD, CAT, and APX activities were, however, maintained over the whole stress treatment.

\section{DISCUSSION}

The significance increase in the carbohydrate content seems to be involved in osmotic adjustment. Total soluble sugars concentrations in the leaf blade after 2 days of drought stress increased by $13 \%$ relative to the control plants. As the stress progressed, the increment in total soluble sugars was more evident (Fig.1). Although, non-reducing soluble sugar concentration still remained higher, that of reducing sugars had dropped. Wardlaw and Willenbrink (1994) have reported that the changes in leaf blade reducing sugars are paralleled by the changes in invertase activity also sucrose synthase activity continuously increasing in the blade with drought stress severity that is consistent with findings results obtained by Tabaeizadeh (1998) which described the correlation between the increase in enzyme activity with drought stress, as well as, non reducing sugars accumulation.

When withholding water, the first signs of stress in maize involved pronounced changes in sugar metabolism. According to our results, the observed variation in the soluble sugars concentrations may be the result of growth being more inhibited by drought stress than photosynthesis, as well as an increased partitioning of fixed carbon to sucrose, as shown for wild species under drought stress (Quick et al.,1992). This accumulation of soluble sugars may be related to osmoregulation and desiccation tolerance (Hare et al., 1998) contributing to plant survival.

The large alterations observed in maize sugar metabolism preceded the drastic decrease of soluble leaf protein. These proteins are typically related to stress responses, such as freezing, osmotic and salt stress and pathogen attack (Chen et al., 1994, Yun et al., 1996, , Tabaeizadeh 1998 and Trudel et al., 1998). Thus the water response of maize seems to have characteristics in common to other adverse conditions in agreement with suggestions made for other species (Tabaeizadeh 1998).

Chlorophyll, carotenoid and photosynthetic rate Drought stress induced changes in the photosynthetic apparatus and the membrane permeability properties of chloroplasts. This fact may be the result of chlorophyll degradation and/or synthesis deficiency together with a decrease of thylakoid membrane integrity (Tabaeizadeh 1998). In the present study, the decline in the chlorophyll content under drought stress may be explained by the earlier structural loss of the chloroplast stroma lamellae, containing photosystem I and most of the chlorophyll a, (Loggini et al.1999). Photoinhibition and photodestruction of pigments may contribute to such changes (Dean et al., 1993). Furthermore, drought stress decreased the capacity to preserve the photosynthetic apparatus. However, it was found in our study that the effect of drought stress is 
likely to follow similar processes to those observed during senescence, severely affected these parameters, therefore the drastic effect by drought stress at chloroplast level may be expected (Tabaeizadeh 1998). Also, the inhibition was probably connected with the increase in the rate of chlorophyll degradation (Garty et al., 1992) through the effect of drought stress on the chlorophyll binding protein, leading to the destruction of chlorophyll that may contribute to such changes(Abdel Nasser 2000). Also, the decrease in the chlorophyll content may also be a phytotoxic consequence of lipid peroxidation and is associated with a decrease in photochemical efficiency. Moreover, the ratio of chlorophyll $a / b$ was more sensitive to the drought stress treatment, showing that $\mathrm{Chl}$ a was more susceptible to water stress, being degraded at a higher rate than $\mathrm{Chl} b$. This can be explained by the fact that part of the decrease in chlorophyll a could be accounted by conversion to chlorophyll $b$ by the oxidation of the methyl group on ring II to the aldehyde (Fang et al., 1998). In this connection Ciscato et al.(1997) have reported that the reduction in the $\mathrm{Chl} a / b$ ratio in maize plant might be due to a direct effect of drought stress on the light harvesting complex of photosystem II (LHC II). Typically, decreases in chlorophyll $a / b$ ratio are observed during senescence (Dean et al., 1993), suggesting that drought stress treatment induced a lower rate of synthesis and accumulation of chlorophyll $a$.

\section{Lipid peroxidation of plasma membrane and $\mathrm{H}_{2} \mathrm{O}_{2}$ content}

Lipid peroxidation has been shown to be one cause of membrane deterioration and disassembly during senescence and is associated with most membrane disorders of plants (Marengoni et al., 1996 a and b). Drought stress was accompanied by increases in the contents of malondialdehyde (MDA) indicating lipid peroxidation and oxidative stress. Drought stress like other environmental stresses can generate the production of a powerful oxidation, which brings about lipid peroxidation, suggesting that fatty acids in thylakoid membrane were targets for drought stress damage. This could be achieved through the activation of toxic $\mathrm{O}_{2}$ molecules that can then attack fatty acids chains resulted in an increase of the membrane damage with a corresponding increase in the formation of MDA in maize leaf. Accordingly, drought stress-induced effect could reflect some modifications of the plasma membrane structure such as the changes in the physical properties of the membrane which reflect the changes in its chemical composition as a result of alteration in metabolic processes (Navari-Izzo et al., 1996). Furthermore, in the present study, there is an accumulation of $\mathrm{H}_{2} \mathrm{O}_{2}$ (Fig. 4A), which acts as a redox signal molecule in plants exposed to drought stress (Mehdy 1994). It has been suggested that $\mathrm{H}_{2} \mathrm{O}_{2}$ functions as a second messenger in plant cells exposed to environmental stresses such as heat (Dat et al.,1998), and pathogens (Levine et al.,1994). Although, $\mathrm{H}_{2} \mathrm{O}_{2}$ inhibits chloroplast sulfhydrylcontaining enzymes by readily oxidizing their sulfhydryl groups, it induces an orchestrated sequence of reactions involving the activation of peroxidases. Therefore, it is important for plant cells to keep the levels of $\mathrm{H}_{2} \mathrm{O}_{2}$ low or to scavenge it efficiently.

\section{Antioxidative defense mechanism}

Reactive oxygen species produced under various abiotic stresses are extremely damaging to lipids, proteins, and pigments unless they are rapidly scavenged by antioxidant enzymes such as SOD, CAT and APX (Asada et al., 1998) to maintain the concentration of any active oxygen species formed at relatively low level. Shalata and Tal (1998) suggested that, the resistance of plants toward environmental stress may depend on the inhibition of ROS production or the enhancement of antioxidant levels. Also, the higher tolerance of some genotypes to environmental stresses has been associated with higher activities of antioxidant enzymes. It is possible that the observed changes in the antioxidant systems occurred as a result of unspecific cellular degradation processes. However, another possibility is that drought stress triggers common defense pathways in plant cells like other biotic or abiotic environmental stresses. In fact, electron spin resonance studies have shown that water-stressed plants displayed elevated concentrations and production rates of superoxide radicals (Price and Hendry 1991).

In maize plants, there were already symptoms of oxidative stress, such as an increase in the total activity of SOD under drought stress and 
retained most of their antioxidant capacity, which may explain why oxidative damage in control plants was incipient compared with stressed plants. The present investigation showed that the increase in APX activity induced by drought stress and remained at a higher level compared to the control suggesting that the increase in the activity of this enzyme can be ascribed at least in part to substrate accumulation. Therefore, the increased APX activity could be the protection against oxidative damage (Tabaeizadeh, 1998). An additional function of the increase in APX activity under drought stress could be related to changes in the cell wall properties, potentially important for the stem in order to cope with the stress. Since drought stress causes the formation of reactive oxygen species.

\section{ACKNOWLEDGEMENT}

The authors extend their appreciation to the Deanship of Scientific Research at King Saud University for funding this work through research group no RGP-VPP 297.

\section{REFERENCES}

1. Abdel Nasser, L. E. Growth, photosynthetic activity and antioxidant efficiency responses to copper treatment in soybean (Glycine max L.) leaves. J. Union Arab Biol., 7: 103-120 (2000).

2. Asada, K. The role of ascorbate peroxidase and monodehydroascorbate reductase in $\mathrm{H}_{2} \mathrm{O}_{2}$ scavenging in plants. In JG Scandalios, ed, Oxidative Stress and the Molecular Biology of Antioxidant Defenses. Cold Spring Harbor Laboratory Press, Cold Spring Harbor, NY, pp 715-735 (1997).

3. Asada, K., Endo, T., Mano, J. and Miyake C. Molecular mechanism for relaxation of and protection from light stress. In K. Sato, N. Murata,eds, Stress Responses of Photosynthetic Organisms. Elsevier Science Publishing, Amsterdam, pp 37-52 (1998).

4. Chen, R. D., Yu, L. X., Greer, A. F., Cheriti H. and Tabaeizadeh Z. Isolation of an osmotic stress- and abscisic acid-induced gene encoding an acidic endochitinase from Lycopersicon chilensis. Mol. Genes and Genetics, 245: 195-202 (1994).

5. Ciscato, M., Valcke R., Van Loven K., Clijsters H., and Navari-Izzo F. Effect of in vivo copper treatment on the photosynthetic apparatus of two Triticum durum cultivars with different stress sensitivity. Physiol. Plant., 100: 901908 (1997).

6. Dat, J., Vandenabeele, S., Vranova, E., Van Montagu, M., Inzé, D., and Van Breusegem, F.. Dual action of the active oxygen species during plant stress responses. Cell Mol Life Sci., 57: 779-795 (2000).
7. Dean, M. A., Letner, C. A. and Eley, J. H. Effect of autumn foliar senescence on chlorophyll $a: b$ ratio and respiratory enzymes of Populus tremuloides. Bull. Torrey Botany Club., 120: 269-274 (1993).

8. Fang Z., Bouwkamp J. C., and Solomos T. Chlorophyllase activities and chlorophyll degradation during leaf senescence in nonyellowing mutant and wild type of Phaseolus vulgaris L. J. Exp. Botany, 49: 503510(1998).

9. Foyer C. H., Descourvieres P. and Kunert K. $J$. Protection against oxygen radicals: an important defense mechanism studied in transgenic plants. Plant, Cell Environ., 17: 507-523(1994).

10. Garty, J., Karary, Y. and Harel, J. Effect of low $\mathrm{pH}$ heavy metals and anions on chlorophyll degradation in the lichen Ramalina duriaei (De Not.) Bagl. Environ. Exper. Botany., 32: 229-241(1992).

11. Hare, P. D., Cress, W. A. and Staden, J. Dissecting the roles of osmolyte accumulation during stress. Plant, Cell and Envir. 21: 535-553(1998).

12. Hodgson, R. A. J and Raison, J. K. Lipid peroxidation and superoxide dismutase activity in relation to photoinhibition induced by chilling in moderate light. Planta., 185: 215-219 (1991).

13. Inskeep, W. P. and Bloom, P. R. Extinction coefficients of chlorophyll $a$ and $b$ in N,Ndimethylformamide and $80 \%$ acetone. Plant Physiol., 77: 483-485(1985).

14. Irigoyen, J., Emerich, D. and Sanchez-Diaz, 
M. Drought stressinduced changes in concentrations of proline and total soluble sugars in nodulated alfalfa (Medicago sativa) plants. Physiol. Plant., 84: 55-60 (1992).

15. Jana, S. and Choudhuri, M. A. Senescence in submerged aquatic angiosperms: Effects of heavy metals. New Phytol., 90: 477484(1982).

16. Levine, A., Tenhaken, R., Dixon, R. and Lamb, C. $\mathrm{H}_{2} \mathrm{O}_{2}$ from the oxidative burst orchestrates the plant hypersensitive disease resistance response. Cell, 79: 583593 (1994).

17. Loggini, B., Andrea, Scartazza, A., Enrico, Brugnoli, E., and Navari-Izzo, F. Antioxidative defense system, pigment composition, and photosynthetic efficiency in two wheat cultivars subjected to drought. Plant Physiol., 119: 1091-1100 (1999).

18. Luck, H. Catalase. In: Bergmeyer HV. Editor. Methods of enzymatic analysis. New York. Academic Press.pp 885-888 (1965)..

19. Marangoni, A. G., Duplessis, P. M., Lencki, R. W. and Yada, R. Y. Low temperature stress induces transient oscillations in sucrose metabolism in Solanum tuberosum. Biophys. Chem., 61: 177-184 (1996b).

20. Marangoni, A. G., Palma, T. and Stanley, D. W. Membrane effects in postharvest physiology. Postharv. Biol. Biotech., 7: 193217(1996a).

21. Mehdy, M. C. Active oxygen species in plant defense against pathogens. Plant Physiol., 105: 467-472(1994).

22. Mittler, R. Oxidative stress, antioxidants, and stress tolerance. Trends Plant Sci., 9: 405410(2002).

23. Navari-Izzo, F., Quartacci, M.F. and Sgherri, C.M.L. Superoxide generation in relation to dehydration and rehydration. Biochim. Soc. Trans. 24: 447-451(1996).

24. Noctor, G. and Foyer, C. H. Ascorbate and glutathione: keeping active oxygen under control. Annu. Rev. Plant Physiol. Plant Mol. Biol., 49: 249-279 (1998).

25. Price, A. and Hendry, G.A. Iron-catalyzed oxygen radical formation and its possible contribution to drought damage in nine native grasses and three cereals. Plant Cell and Environ. 14: 477-484 (1991).

26. Quick, W.P., Chaves, M.M., Wendler, R., David, D., Rodrigues, M.L., Passarinho, J.A., Pereira, J.S., Adcock, M.D., Leegood, R.C. and Stitt, M. The effect of drought stress on photosynthetic under field conditions. Plant, Cell and Environ., 15: 25-35 (1992).

27. Schwanz, P., Picon, C., Vivin, P., Dreyer, E., Guehl, J. and Polle, A. Responses of antioxidative systems to drought stress in Pendunculate Oak and Maritim Pine as modulated by elevated $\mathrm{CO}_{2}$. Plant Physiol., 110: 393-402 (1996).

28. Shalata, A. and Tal, M. The effects of salt stress on lipid peroxidation and antioxidants in the leaf of the cultivated tomato and its wild salt-tolerant relative Lycopersicon pennellii. Physiol. Plant., 104: 169-174 (1998).

29. Stewart, R. R. C. and Bewley, J. D. Lipid peroxidation associated with accelerated ageing of soybean axes. Plant Physiol., 65: 245-248 (1980).

30. Tabaeizadeh, Z. Drought-induced responses in plant cells. Inter. Rev. of Cytology, 182:193247(1998).

31. Takeda, T., Yokota, A., and Shigeoka, S. Resistance of photosynthesis to hydrogen peroxide in algae. Plant Cell Physiol., 36: 1089-1095 (1995).

32. Trudel, J., Grenier, J., Potvin, C. and Asselin, A. Several thaumatin-like proteins bind to $B$ 1,3-glucans. Plant Physiol., 118: 1431-1438 (1998).

33. Wardlaw, I. F. and Willenbrink, J. Carbohydrate storage and mobilization by the culm of wheat between heading and grain maturity: the relation to sucrose synthase and sucrose-phosphate synthase. Aust. J. Plant Physiol., 21: 255-271(1994).

34. Yun, D. J., D'Urzo, M. P., Abad, L., Takeda, S., Salzman, R., Chen, Z., Lee, H., Hasegawa, P. M. and Bressan, R. A. Novel somatically induced antifungal chitinases and bacterial expression of an active recombinant isoform. Plant Physiol., 111: 1219-1225(1996). 